
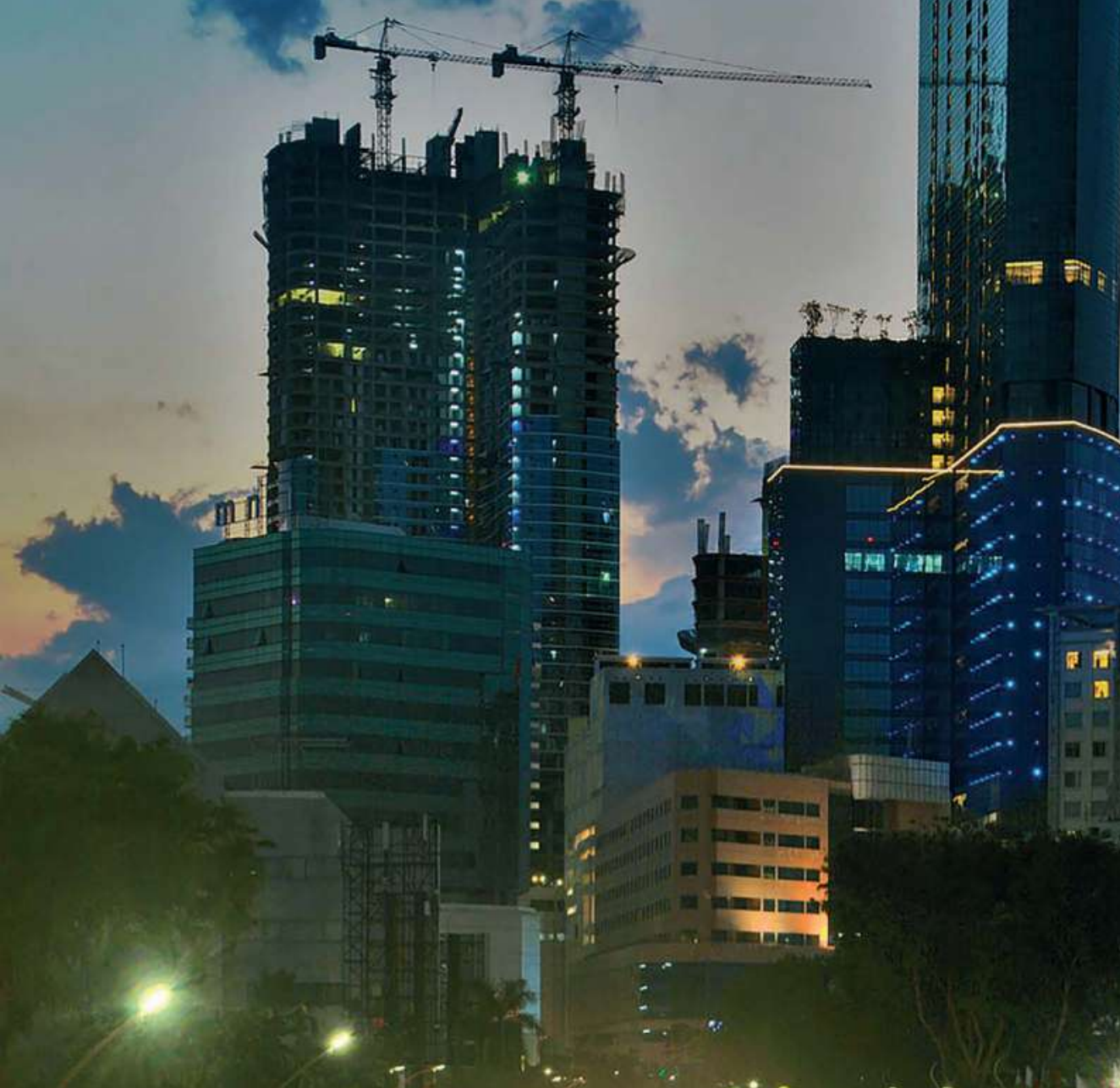

\section{Editors}

Badri Munir Sukoco

Rahmat Heru Setianto Nidya Ayu Arina Ade Gafar Abdullah Asep Bayu Nandiyanto Ratih Hurriyati

\section{Increasing Management Relevance \\ and}

\section{CPD \\ CERTIFIED

(ci. C) CRC Press

A BALKEMA BOOK 
PROCEEDINGS OF THE $2^{\text {ND }}$ GLOBAL CONFERENCE ON BUSINESS, MANAGEMENT AND ENTREPRENEURSHIP (GC-BME 2017), AUGUST 9, 2017, UNIVERSITAS AIRLANGGA, SURABAYA, INDONESIA

\section{Increasing Management Relevance and Competitiveness}

Editors

Badri Munir Sukoco, Rahmat Heru Setianto \& Nidya Ayu Arina Universitas Airlangga, Indonesia

Ade Gafar Abdullah, Asep Bayu Nandiyanto \& Ratih Hurriyati Universitas Pendidikan, Indonesia

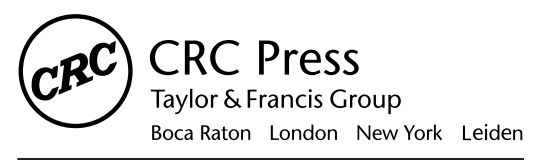

CRC Press is an imprint of the

Taylor \& Francis Group, an informa business

A BALKEMA BOOK 
CRC Press/Balkema is an imprint of the Taylor \& Francis Group, an informa business

(C) 2018 Taylor \& Francis Group, London, UK

Typeset by V Publishing Solutions Pvt Ltd., Chennai, India Printed and bound in Great Britain by CPI Group (UK) Ltd, Croydon, CR0 4YY

All rights reserved. No part of this publication or the information contained herein may be reproduced, stored in a retrieval system, or transmitted in any form or by any means, electronic, mechanical, by photocopying, recording or otherwise, without written prior permission from the publisher.

Although all care is taken to ensure integrity and the quality of this publication and the information herein, no responsibility is assumed by the publishers nor the author for any damage to the property or persons as a result of operation or use of this publication and/or the information contained herein.

Published by: CRC Press/Balkema

Schipholweg 107C, 2316 XC Leiden, The Netherlands

e-mail: Pub.NL@taylorandfrancis.com

www.crcpress.com - www.taylorandfrancis.com

ISBN: 978-0-8153-7455-8 (Hbk)

ISBN: 978-1-351-24189-2 (eBook) 


\section{Table of contents}

Preface $\quad$ xi

$\begin{array}{lc}\text { Acknowledgements } & \text { xiii }\end{array}$

$\begin{array}{ll}\text { Organizing committees } & \mathrm{XV}\end{array}$

Strategic management, entrepreneurship and contemporary issues

Governance of financial intangible success factors: An option in building business resilience and sustainability

P. Sugito

The influences of the alliance learning process and entrepreneurial orientation on the strategic alliance performance of Indonesian construction companies R. Handayani \& R. Dyah Kusumastuti

Assessing necessity and opportunity-based entrepreneurship: An analysis of demographic characteristics, propensity for new ventures and entrepreneurial motivation (a study of labor forces and entrepreneurs in Padang, Indonesia)

H. Rahman \& D. Lesmana

Critical assessment on zakat management: Zakat scorecard model

T. Widiastuti, S. Herianingrum \& I. Mawardi

Investigating entrepreneurial orientation impact on project performance in highly regulated industry: A case of renewable power industry in Indonesia

F.A. Firman, R.D. Kusumastuti, H.T. Kurniawan \& I.M. Ruky

How to survive in the modern era: Integrated local entrepreneurs, the traditional market and the modern store

P.P.D. Astuti, Y. Setyowati \& A.A.G.S. Utama

xi iii

XV

The influence of Islamic service quality toward bank customer loyalty and satisfaction of

BRISyariah Surabaya

M.Q. Fauzi, S. Herianingrum, T. Widiastuti \& R. P. Putra

Management accounting practices in micro enterprises in the Sleman Regency, Daerah

Istimewa Yogyakarta

A.C. Laksmi \& A.P. Putra

The power of finance: The dynamics of female entrepreneurs in fulfilling their financial needs

M.R. Rita, S. Wahyudi \& H. Muharam

Entrepreneurial orientation in a family business group: The role of the corporate center and its effect on business unit performance

O. Pendrian, K.A. Karnen, R. Rachmawati \& R.D. Kusumastuti

Developing entrepreneurship for the performing arts community through an art incubation model

J. Masunah \& R. Milyartini

Capability to contest on market performance

61

B. M. Sukoco \& R. R. Maulana 
The influence of the socio-economic status of parents toward entrepreneurial attitudes H. Mulyadi, M. Arief Ramdhany \& S. Sulastri

Analysis of the factors affecting the elected mode of transportation for workers using an analytical hierarchy process

E. Mahpudin \& H. Sulistiyo

71

75

Multidimensional approach for assessing service quality in the service industry

Y.D. Lestari

The influence of entrepreneurship orientation and management capability on performance of small and medium enterprises in Bogor

A. Setyo Pranowo, H. Hari Mulyadi, Z. Musannip Efendi Siregar \&

Y. Hendayana

The influence of family factors on expatriate performance

N. Kartika

Is firm size an important determinant for firms in establishing political connections?

N.N. Amorita, D. Agustia \& I. Harymawan

Integration of corporate social responsibility and resource based theory to create

and capture value

N. Nandang \& H. Mulyadi

Organizational behavior, leadership and human resources management

Superior performance model of human resources

T. Yuniarsih, Disman \& M.D. Sugiharto

The impact of fiscal decentralization on economic growth and manpower absorbed at districts/cities in South Kalimantan Province

Muzdalifah \& R. Purwono

Work-family conflict and satisfactions: A job demand-resources model perspective

J. Sulistiawan

Building employee engagement through transformational leadership, psychological empowerment and affective commitment

P. Yulianti \& N. Hamidah

The impact of transformational leadership, learning organization and job autonomy on creative self-efficacy

I. B. G. A. Permana \& W. Astiti

Enhancing commitment to organizational change initiative and performance outcomes N.A. Arina \& P. Yulianti

The influence of Perception of Usefulness (PoU) and Perceived Ease of Use (PEU) on the perception of information system performance

F. Sayekti \& L.E. Wijayanti

Knowledge sharing benefits: The contingency effects of environmental contexts

A. Qomariyah

The antecedents of entrepreneurial intentions in students of Airlangga university

(A study of student participants in WEBS in the faculty of economics and business)

P. Yulianti \& I. G.N.W.H. Saputra

Effect of proactive personality and Organizational Support for Career Development (OSCD) on career satisfaction and job performance

V. Octia \& D. Ratmawati

The effects of transformational and transactional leadership on work performance of middle-level leaders with organizational commitment as mediator: A study of state-owned company, Pelabuhan Indonesia III Inc.

A. Eliyana, S. Maarif \& R.J. Sunarsono 
Transformational leadership style, team performance and team job satisfaction:

Mediation by levels of cognitive trust and collective efficacy

P. Yulianti \& R. Sanjaya

The impact of self-efficacy and perceived organizational support on operational managers' readiness to change

H. Prima \& A. Eliyana

\section{Marketing management}

Factors affecting customer retention in a priority banking program

I.R. Aliyah, S. Soebandhi \& A. Baktiono

The impact of messages assertiveness on compliance with perceived importance as a moderation variable on the anti-cigarette campaign in Surabaya

Kristiningsih, R.S. Wuryaningrum \& A. Trimarjono

Demographic variables and environmentally friendly behavior in a developing country

T. Handriana

Antecedents and consequences of ongoing search information

D. T. Firmansyah \& D. Mardhiyah

Role of negative brand name perception and religiosity on brand attitude

S. Gunawan \& R.T. Ratnasari

The effects of good/bad news on consumer responses toward higher education

G.C. Premananto \& M.H. Hanafiah

Examining leadership style and advertising evaluation on employees'

customer focus

R.A. Aisyah \& N.A. Arina

The effect of airline sale promotion types on consumers' attitudes toward brand and purchase intentions

M. Kurniawati

The influence of celebgrams, e-WOM, and pictures on impulse buying

Hartini, Sri \& Uswatun

Value propositions of supermarkets

R. Rinawati

Empirical study of perceived quality information and perceived information security impact on online purchasing in Indonesia

L. Lisnawati, L.A. Wibowo \& P. Andi

Measuring religiosity and its effects on attitude and intention to wear a hijab:

Revalidating the scale

H.A. Wibowo \& M.R. Masitoh

\section{Management and economics education}

Communication skills of accountants and managers in Indonesia

Y.L. Rudianto \& A.R. Sridadi

Factors knowledge management and the work motivation of lecturers

Rino

The role of talent management in student performance in higher education

D. Purwaningsih

Strategy to build universities

P. Dewi Dirgantari, B. Widjajanta \& L. Lisnawati

Factors affecting the improvement of students' Grade Point Average (GPA)

A.B. Santoso, E.C.M. Simatupang \& R.H. Sofyandi 
Innovation, operations and supply chain management

Analysis of the small segment credit business process at Bank ABC Indonesia

A.C. Saifullah \& R.D. Kusumastuti

The identification of defects in rubber slipper production using the six sigma method

T.A. Auliandri \& M.A. Setiani

The design of service quality improvement in a library by using LibQUAL model and fishbone diagram

F. Wurjaningrum \& A. Kurniawan

The strategic role of Indonesia in Global Value Chains (GVC)

M.A. Esquivias, D. W. Sari \& R.D. Handoyo

N. Anridho

Efficiency and total-factor productivity in the manufacturing industry in

33 provinces of Indonesia

Muryani

Academic excellence and total quality supply chain management in higher education

I. Usman \& Windijarto

Financial management and accounting

The influence of usage accounting information on small medium enterprise's perception

S. Mintarti, D. M. Sari \& T. Fitriastuti

Determinants of banks' net interest margin in five South East Asian countries

M. Gitanadya \& R. Setiawan

The effect of monetary policy and macroeconomic variables on foreign portfolio investment in Indonesia

N.F. Anne \& R. Purwono

Internal factors, external factors, and bank liquidity in Indonesia

I.M. Sudana \& A.F. Akbar

The obstacles in developing Indonesia's sovereign sukuk

N. Laila, F.F. Hasib \& M. Anshori

The effect of trading volume changes on JKSE's market return

M. Madyan, S. Hasan \& D.F. Putri

The influence of the profitability indicator, capital and performing loans on the liquidity of the bank in the Indonesian stock exchange

O.V.B. Nainggolan

Corporate governance performance evaluation of banks operating in Indonesia

F. Budhijono

What drives finance pattern debt companies to pay dividends in Indonesia?

L. Gestanti \& G. Memarista

Diversification, firm value and government ownership

S. A. Usman \& C. Sulistyowati

Do operating costs, investment returns and claims have an effect on contributions?

D.F. Septiarini

S.R. Arifin \& Wisudanto

Different ways to solve the liquidity problem of Indonesian Islamic microfinance

I. Mawardi \& T. Widiastuti 


\section{Preface}

International Conferences provide an excellent opportunity to bring together academics from different countries and backgrounds for the purpose of presenting their research results, critically discussing methodology and findings and improving the quality of research and the impact of the research on society and science. Furthermore, conferences enable the scientific community to create new networks, to foster relationships and extend their visibility.

The 2nd Global Conference on Business Management and Entrepreneurship (GCBME) 2017 is an annual conference co-hosted by Department of Management, Faculty of Economics \& Business, Universitas Airlangga and Business Management Education Program, Faculty of Business and Economics Education, Universitas Pendidikan Indonesia. The theme of GCBME 2017 is increasing management relevance and competitiveness.

The theme inspired by the concern of Sumantra Ghoshal that bad management theories are destroying good management practices. Before that, the dichotomy between rigor and relevance is always becoming a hot topic in the management field. This conference aims to answer the following question: How might we accomplish a reconciliation of rigor (academic) and relevance (practitioner) standards to offer organizational competitiveness?

I expect this conference raises two important things in the discussion room and proceedings (based on Corley and Gioia, 2011): First, theories used in this conference should be problem driven-that is addressing a problem of direct, indirect, or long-linked relevance to practice, rather than narrowly addressing the (theoretical) "problem." Second, the fact that we are a profession (academia) studying another profession (management), therefore it needs balancing between theoretical contribution managerial implications. By doing that, I believe that our research and discussion in this conference could offer something useful for practitioners (thus increase its competitiveness) while at the same time contribute to the development of our management field.

I am looking forward to seeing you in GCBME in the near future.

With warmest regards,

Prof. Badri Munir Sukoco, $\mathrm{PhD}$

GC-BME 2017 Conference Chair 
Increasing Management Relevance and Competitiveness - Sukoco et al. (Eds) (C) 2018 Taylor \& Francis Group, London, ISBN 978-0-8153-7455-8

\section{Acknowledgements}

Badri Munir Sukoco, Universitas Airlangga, Indonesia Ratih Hurriyati, Universitas Pendidikan Indonesia Ade Gafar Abdullah, Universitas Pendidikan Indonesia Praptini Yulianti, Universitas Airlangga, Indonesia Muhammad Madyan, Universitas Airlangga, Indonesia Didi Sukyadi, Universitas Pendidikan Indonesia Wann-Yih Wu, Nanhua University, Taiwan John Nowland, Illinois State University, USA

Ikuro Yamamoto, Kinjo Gakuin University Nagoya, Japan

Jon Lovett, University of Leeds, UK

John Paul, Kedge Business School, France

Ranbir Malik Singh, Curtin University, Australia

Nobuhide Otomo, Kanazawa University, Japan

Mohamed Dahlan Ibrahim, Universiti Malaysia Kelantan, Malaysia

Dadang Kurnia, GIZ, Germany 


\section{Organizing committees}

\section{ADVISORS}

Prof. John Paul

Prof. Ranbir Malik Singh

Prof. Dr. Nobuhide Otomo

Prof. Dr. Mohamed Dahlan Ibrahim

Prof. Dr. Anis Eliyana

Prof. Dr. Muslich Anshari

Prof. Dr. Fendy Suhariadi

Prof. Dr. Sri Iswati

Prof. Dr. Bambang Tjahjadi

Prof. Dr. Nanang Fattah

Prof. Dr.Agus Rahayu

Prof. Dr. Tjutju Yuniarsih

Prof. Dr. Disman

Prof. Dr. Suryana

Prof. Dr. Eeng Ahman

Prof. Dr. Ratih Hurriyati

Prof. Ina Primiana

\section{CONFERENCE CHAIR}

Prof. Badri Munir Sukoco, Ph.D

\section{COMMITTEES}

Dr. Tanti Handriana

Rahmat Heru Setianto, SE, M.Sc.

Nidya Ayu Arina, SM, MSM.

Dr. Masmira Kurniawati

Made Gitanadya, SE, MSM.

Ratri Amelia Aisyah, SM, MSM.
Prof. Lincoln Arsyad

Prof. Gunawan Sumodiningrat

Dr. Phil Dadang Kurnia

Assoc. Prof. Arry Akhmad Arman

Assoc. Prof. Dwilarso

Assoc. Prof. Hardianto Iristidi

Assoc. Prof. Rachmawaty Wangsaputra

Assoc. Prof. Teungku Ezni Balkiah

Assoc. Prof. Ruslan Priyadi

Assoc. Prof. Sri Gunawan,

Assoc. Prof. Dr. Indrianawati Usman

Assoc. Prof. Yudi Aziz

Assoc. Prof. Lili Adiwibowo

Assoc. Prof. Vanessa Gaffar

Assoc. Prof. Chaerul Furqon

Vina Andriany MEd, PhD

Tutin Ariyanti, $\mathrm{PhD}$ 


\title{
Different ways to solve the liquidity problem of Indonesian Islamic microfinance
}

\author{
I. Mawardi \& T. Widiastuti \\ Universitas Airlangga, Surabaya, Indonesia
}

\begin{abstract}
Baitul Maal wa Tamwil (BMT), which is a form of Islamic microfinance institution in Indonesia, faces liquidity problems. This study aims to map out the liquidity problems faced by BMTs, to discover how BMTs are addressing the different problems and to find a BMT model of liquidity management. This study used a qualitative approach using the case study analysis techniques of Robert K. Yin. Subjects of this study are BMTs in East Java, which were selected purposively with ten BMT managers as key informants. The results show that there are five different ways used by BMTs in overcoming liquidity. BMTs were established as formal securities guarantor institutions, in the form of a secondary cooperative that consists of BMTs, taking a standby loan from Islamic banks which can be taken when needing liquidity, establishing non-formal inter-BMT relations, borrowing from other financial institutions, and having individual backing that can be borrowed at any time. The best way to manage the liquidity of BMTs is to form a secondary cooperative, because it can also act as an alternative for BMTs to save funds when there is excess liquidity.
\end{abstract}

Keywords: Islamic microfinance, baitul maal wa tamwil, liquidity problem, cooperative

\section{INTRODUCTION}

An Islamic microfinance institution, Baitul Maal wa Tamwil (BMT), is an intermediary financial institution such as a bank, operating in the micro sector. BMTs receive deposits from surplus units and disburse them in the form of financing to customers in need (deficit units). As a sharia intermediary financial institution, the BMT runs it's operations according to Islamic sharia. From the financing side, BMTs will earn revenue, where some will be given to the depositor (shahibul mal) and some will be the income of the BMT (Ridwan, 2006, 34).

In BMTs, liquidity risk emerges as one of the most important risks, where BMTs need to handle it in order to avoid greater losses. As an intermediary institution that relies on trust, failure to regulate liquidity will impact on other risks. Liquidity risks are broadly defined as potential losses for financial institutions, arising from their inability to meet obligations or to fund asset increases when they mature without incurring unacceptable costs or losses (Dusuki, 2005; Greuning \& Bratanovic, 1999). This risk occurs when depositors collectively decide to withdraw their funds in greater amounts than the funds owned by the institution (Hubbard, 2002, 323), or when borrowers fail to meet financial obligations.

In practice, one of the main objectives of liquidity management is to maintain assets and liabilities. Among these are managing financing and financing activities, estimating funding and financing requests, as well as maintaining a reserve fund to meet its financial obligations to third parties. Sharia intermediary financial institutions have unique characteristics because BMT operations must comply with sharia principles. Therefore, the arrangement of liquidity management mechanisms in these financial institutions requires extra effort and special attention. Liquidity risk in the intermediary financial institution arises when the business in the real sector decreases, resulting in a failure to perform proper liquidity management.

In principle, sharia intermediary financial institutions seek to provide good liquidity management on real business transactions. This is because each financing contract with a real asset in a sharia intermediary financial institution is unique, compared to that of a conventional one. Therefore, in operation, sharia intermediary financial institutions should consider business cycles, cooperation among business partners, and deal with stakeholders to avoid any liquidity risk arising from the disharmony of business partners or unfavorable business conditions.

The intermediary Islamic finance institution also acts as a financial intermediary, supporter and facilitator, as well as positioning itself as a trusted body for investors and business partners. Thus, liquidity management in BMTs is done based on 
trust, confidence and support from each other. In the context of banking in Indonesia, both sharia and conventional banks, in the case of solving liquidity problems, guarantees are provided by a third-party deposit guarantee institution (LPS) and are bound by the regulator to provide savings, such as the minimum reserve requirement in the banking system, so that the liquidity problem in the bank can be overcome.

As a financial intermediary institution like sharia banks, a BMT is faced with greater liquidity problems. In addition to having to consider profitability with more release financing, a BMT faces problems not faced by sharia banking. Firstly, BMTs do not have a third-party deposit guarantee institution; secondly, BMTs are not bound by regulators to provide savings, such as minimum statutory reserves in banks that function as a source of liquidity when experiencing problems. These reasons underlie this research to find the way or mechanism of a BMT in overcoming its liquidity problem.

\subsection{Function of liquidity}

Liquidity for intermediary financial institutions is very important. Therefore, the level of liquidity reflects the ability of intermediary financial institutions to meet financial obligations that must be met immediately. According to Kuncoro and Suhardjono (2002, 279), liquidity is the ability of the intermediary financial institution to provide sufficient funds to meet all its obligations, as well as commitments, which have been issued to its customers at any time. According to Wood et al (2004, 153), liquidity is the ability of intermediary financial institutions to meet all withdrawal of funds by the depositors, clients and liabilities that have matured, and to meet the demand for credit without any delay.

According to Taswan (2006, 97), liquidity may serve as follows: a) to indicate that the intermediary financial institution is a safe place to save money; b) to enable intermediary financial institutions to fulfill their credit commitments; c) to avoid the sale of unprofitable assets; and d) to minimize the risk assessment of the inability to pay the obligation to withdraw the funds.

\subsection{Liquidity management policy}

The liquidity management process begins with the establishment of a liquidity management policy by the Board of Directors as the primary guideline for all entities in the organization. For this purpose, there are at least three implementation requirements: a) the Board of Directors should understand the bank's liquidity risk profiles and internal/ external business environment, and stimulate the liquidity risk tolerance; b) the Board of Directors shall determine and agree on liquidity risk management strategies, policies and practices; and c) the Board of Directors shall deploy, communicate and guide senior managers to manage liquidity effectively (BCBS, 2008).

Following liquidity management policies and the role of liability committees of assets and their peers, effective information systems need to support the liquidity management processes (BCBS, 2008). This system allows Lembaga Keuangan Syariah (LKS) to monitor, report and control liquidity risk exposures, and determine funding needs within and outside the organization. In general, an effective information system concerns two players, namely, decision-makers of liquidity management and decision-makers at the operational level.

In order to maintain the soundness of the liquidity management process, financial institutions must have an internal control system, to adhere to the processes undertaken by decision-makers with a single set of decision-makers (BCBS, 2008). This internal control system can be assigned to the Asset Liability Committee (ALCO) as a representative of the directors to bridge the gap between the decision-makers. However, regular functions of a comprehensive internal control system audit the liquidity management process, to evaluate liquidity positions, and if necessary, to propose revisions or improvements of the liquidity management process to the Board of Directors (decision-makers).

\subsection{Identification and measurement of liquidity risk}

Measurement of liquidity risk in a BMT can be done in four ways. First, the funding structure, namely the assessment of the structure of deposits by type, term, currency, interest rate, fund owner and concentration of funds ownership. Second, expected cash flow, which is the assessment of all cash inflows and cash outflows, including funding, needs to meet commitments on administrative account transactions to identify possible future funding shortages. Third, market access, in other words the assessment of the ability of intermediary institutions to obtain liquidity in the market, both under normal conditions and in abnormal conditions. Fourth, marketability asset, which is the assessment of liquid assets that can be converted into cash, especially in abnormal conditions (crisis), when the BMT is not able to fulfill all obligations by using positive cash flow owned and loaned from the money market.

Liquidity calculation can be done by arranging a maturity profile (maturity ladder) for each type of scenario, by arranging cash flow based on maturity or estimation using an assumption based on 
past experience. If the cash flow forecast is based on estimated statistical data, the accuracy and precision of the estimate should be periodically reassessed. In addition, the assumptions and variables used in these estimates should be reviewed in accordance with changing market conditions, competitive factors and changes in customer behavior (Muhamad, 2009, 74).

\subsection{Liquidity as sharia responsibility}

Good liquidity management shows good sharia implementation as well. Sharia implementation is a good consequence for sharia financial institutions that will get closer to the achievement of the goal of sharia, the maslahah. The better implementation of sharia will have a positive impact on BMTs. Therefore, Allah has promised a blessing that can be interpreted as achievement of performance and the better benefits of a BMT for anyone who implements Sharia properly. In surah Al A'raf (7) verse 96, Allah says that for anyone who believes and is cautious to Allah, which means to observe the sharia of Allah by doing what is commanded and away from what is forbidden by Allah, Allah will give blessings and prosperity.

This means that if the BMT implements Islamic sharia correctly, then the performance of the BMT will be good and will affect the benefit for all. Vice versa, if the implementation of sharia in the BMT is bad, then the difficulties will also hit the BMT. Allah has declared that if implementing the sharia of Allah is below par, Allah promises shame, as explained in Surah Al-Baqarah (2) verse 85. Both verses above show that the implementation of sharia is very important for BMT, because the implementation of sharia is closely related to the achievement of the purpose of implementation of sharia, namely maqashid sharia or maslahah.

\section{RESEARCH METHOD}

\subsection{Research approach}

This research uses qualitative approach with the case study approach of Robert K. Yin. Subjects of this study are BMTs in East Java that were selected purposively with ten BMT managers as key informants. A survey research design involves selecting respondents and receiver samples of questionnaires (McMillan \& Schumacher, 1993). Primary data is collected by using structured interviews with the participation of BMT managers.

This study assumes that BMT managers are involved, either directly or indirectly, to solve liquidity problem in BMTs. Purposive sampling is used to select managers of BMTs in East Java that know exactly how to manage liquidity and solve liquidity problems. In addition, managers responsible for BMTs in the study area (i.e. the operations manager and BMT employees) are used as additional informants.

\subsection{Data analysis technique}

The data analysis technique of this research uses content analysis method. Content analysis methods are defined as techniques for drawing conclusions by identifying the specific characteristics of a message objectively, systematically and generally (Holsti, 1969, 14). This method is intended to analyze all discussion about the concept of solving BMTs' liquidity problems.

The author prepares the basic procedures for the design of research and the execution of content analysis studies, consisting of six steps for data analytics: a) stages of formulating research problems; b) arranging the conceptual framework of the research concept operationalization; c) data collection by sampling the selected data sources; d) creation of categories used in the analysis; e) data collection of selected documents; and f) interpretation of data obtained.

\section{RESULT AND DISCUSSION}

\subsection{Form of BMT liquidity risk}

As a business institution, a BMT acts as a financial intermediary institution. BMT receives deposits from third parties with surplus funds and then distributes these to parties who need funds (minus). The short-term nature of deposits and long-term financing make BMTs often experience liquidity difficulties. Of the 128 BMTs questioned, all claimed to have experienced liquidity difficulties.

Even so, according to the BMT managers, liquidity difficulties can be anticipated. Therefore, liquidity difficulties can be predicted as to when they occur, so they can be prepared for. The main cause of liquidity difficulties experienced by BMTs is the commemoration of religious holidays, such as Ramadhan and Idul Fitri, the new school year, and planting season. This is as revealed by Nyakdin, the director BMT Pahlawan Tulungagung: 'Historical data about customer behavior is an important lesson in regulating liquidity. Before Ramadan, we relax the financing to increase cash for withdrawals during Ramadan. So is July, because of the new school year.'

The importance of liquidity is well understood by BMTs. According to Abdul Madjid Umar, director BMT UGT Sidogiri, which is the largest BMT in Indonesia, as an intermediary institution, 
regulating liquidity is very important for BMTs. Therefore, liquidity is the pulse of intermediary financial institutions, so that if it fails to regulate liquidity, then the future of the BMT business will be destroyed.

Liquidity is a trade off of profitability, so it must be carefully arranged. If liquidity is good then generally profitability is disrupted, and vice versa, if profitability is good then liquidity is threatened. Because, to maintain liquidity, a BMT needs to reserve a certain amount of funds so that if at any time these are taken by the depositors, the BMT will have no liquidity problem. However, the reserve fund is idle, so it cannot be used to make profit.

From this study, it is found that 82 of 128 BMTs $(64 \%)$ claim to be able to solve their own liquidity problems. BMTs that can overcome their own liquidity problems rely on customer deposits to do so (35 of 46 BMTs). In addition, by linkage with other financial institutions, either with sharia banks, other BMTs or other financial institutions, some BMTs rely on multiple sources at once.

From this fact, it appears that linkage becomes very important for BMTs. If they cannot rely on customer deposits to cope with the usually urgent liquidity, then they rely more on linkage with Islamic financial institutions. During this time, most BMTs in East Java are already doing linkage with Sharia banks. Meanwhile, of the BMTs that cannot cope with their own liquidity problems, $48 \%$ rely on ownership capital (first rank), other BMTs $(13 \%)$, the government $(13 \%)$, and on personal bank loans.

From this study, BMTs which can solve their own liquidity difficulties perform productivity improvement measures $(36 \%)$, internal process optimization (32\%), and productivity improvement $(32 \%)$. These three are quite effective in overcoming liquidity difficulties independently. Generally, those who do this are BMTs which are experienced in performing their intermediary function, so they already know when liquidity difficulties will occur, such as before Idul Fitri, the new school year, and planting season for farmers.

Activities in addressing the need for liquidity independently in BMTs in East Java are very diverse. In optimizing the internal process, this is done by reducing the financing $(40 \%)$ and increasing the capital $(53 \%)$, while the efficiency step is done by reducing the operational cost $(51 \%)$ and the optimization of working hours. In improving productivity, this is done to improve employee performance (47\%) and billing (45\%).

The various ways BMTs solve liquidity problems can be differentiated in five different ways. Firstly, BMTs establish a formal guarantor institution in the form of a secondary cooperative which consists of the BMT, namely the Center for Sharia Cooperatives and Parent Sharia Cooperatives.

In East Java, there are five secondary sharia cooperatives. This secondary cooperative consists of other institutions, namely the primary cooperative BMT. Primary BMTs that lack liquidity can obtain liquidity from secondary cooperatives. Likewise, the primary cooperative BMTs that have excess liquidity can place funds in secondary cooperatives. Thus, the secondary cooperative becomes a lender of last resort for the BMT. 'We set up a secondary cooperative, recognizing the importance of places to place excess liquidity or otherwise seek funding when there are liquidity shortages,' said Nyakdin, director of BMT Pahlawan in Tulungagung as informant.

BMT Pahlawan, along with 39 other BMTs in Tulungagung, Blitar and Trenggalek districts, form a secondary sharia cooperative called Center for Sharia Cooperatives (Puskopsyah). In addition, 40 BMTs affiliated with the Indonesian Islamic Da'wah Institution (LDII) form a secondary cooperative BMT. Similarly, 40 BMTs under Aisiyah Muhammadiyah East Java form a secondary cooperative Bueka As-sakinah East Java.

Second, BMTs adopt the financing of a standby loan at a sharia bank, which can be taken at any time when liquidity difficulties occur. In general, BMTs have assets and are bankable, so it is easy to obtain financing in sharia banks. In fact, many BMTs have linkage with sharia banks, not only in case of liquidity difficulties, but also to enlarge the reach of financing. This is done by BMT UGT Sidogiri, BMT Maslahah Sidogiri Pasuruan, and BMT Mandiri Sejahtera Gresik.

Third, in establishing non-formal inter-BMT relations. BMTs that are in one region generally have a close relationship that can help one another. Likewise, BMTs are affiliated in an organization's ties, such as Muhammadiyah, Nahdhatul Ulama, and the Indonesian Islamic Da'wah Institution (LDII). Therefore, they usually form non-formal relationships to help each other when needed, including in overcoming the lack of liquidity, or vice versa.

Fourth, by borrowing from other financial institutions, either other BMTs, sharia banks, or Bank Perkreditan Rakyat Syariah (BPRS). BMTs that use this method generally do not have a good relationship with other BMTs, so when faced with liquidity difficulties, they seek loans from other financial institutions.

Fifth, by having individual backing that can be borrowed at any time. This step is usually done by BMTs with relatively small assets. Usually, people who can lend to a BMT have an ongoing business relationship, such as customers or administrators. When experiencing liquidity difficulties, BMT management borrows short-term funds from them. 
Table 1. Problem solving of liquidity risk in BMTs.

$\begin{array}{ll}\text { Problem of liquidity risk in BMTs } & \begin{array}{l}\text { Result } \\ \text { BMT doing linkage with other financial institutions, either linkage with sharia } \\ \text { banks, linkage with other BMT or other financial institutions. }\end{array} \\ \begin{array}{c}\text { Functional Activities of Credit } \\ \text { (Provision of Funds), }\end{array} & \text { cooperative BMTs that excess liquidity can place funds on secondary cooperatives. } \\ \text { Treasury Investments, } & \text { Thus, the secondary cooperative becomes a lender of last resort for the BMT. } \\ \text { Financing Activities and } & \text { BMT takes the financing of a stand by loan at a sharia bank that can be taken } \\ \text { Debt Instruments. } & \text { at any time when liquidity difficulties occurred. } \\ & \text { Establishing non-formal inter-BMT relations. } \\ & \text { Have individual backing that can be borrowed at any time. } \\ \text { To borrow to other financial institutions, both to other BMT, sharia banks, or BPRS. }\end{array}$

The best way to overcome the liquidity problem of a BMT is to form a secondary cooperative, because it can also be an alternative for BMTs to place funds when there is excess liquidity.

\section{CONCLUSION AND RECOMMENDATIONS}

The main cause of liquidity difficulties that are often experienced by BMTs is the commemoration of religious holidays, such as Ramadan and Eid al-Fitr. In addition, other causes of liquidity difficulties are the new school year, and the planting season. Most BMTs can solve liquidity problems by relying on customer deposits to overcome their liquidity, linkage with other financial institutions, linkage with sharia banks, other BMTs, and with the Bank Perkreditan Rakyat Syariah (BPRS). BMTs that cannot cope with their own liquidity rely on ownership capital, from other BMTs, the government, and Islamic or personal bank loans. BMTs that can solve their own liquidity difficulties use productivity improvement measures, internal process optimization and increased productivity. These three things are quite effective in overcoming liquidity difficulties independently.

There are five ways in which BMTs can overcome liquidity difficulties. First, the BMT is established as a formal guarantor institution in the form of a secondary cooperative, which consists of the BMT, namely the Center for Sharia Cooperatives (Puskopsyah). There are at least five Puskopsyah in East Java. Second, BMTs cooperate with sharia banks by opening a standby loan which can be taken at any time when facing liquidity difficulties. Third, by establishing non-formal inter-BMT relations. Fourth, by borrowing from other financial institutions, be it from a BMT and or Bank Perkreditan Rakyat Syariah (BPRS). Fifth, in having individual backing that can be borrowed at any time. The best way to overcome the liquidity problems of a BMT is to form a secondary cooperative, because it can also be an alternative for BMTs to place funds when facing excess liquidity.

\section{REFERENCES}

Aggarwal, R.K. \& Yousef, T. (2000). Islamic Banks and Investment Financing. Journal of Money, Credit and Banking, 32(1), 93-120.

Akhtar, M.F., Khizer, A. \& Shama, S. (January 2011). Liquidity Risk Management: A Comparative Study Between Conventional and Islamic Banks of Pakistan. Interdisciplinary Journal of Research in Business, 1(1), 35-44.

Allen, F. \& Santomero, A.M. (1998). The Theory of Financial Intermediation. Journal of Finance and Banking, 36(3), 454-480.

Arun, T.G. \& Turner, J.D. (2002). Financial Sector Reform in Developing Countries: The Indian Experience. The World Economy, 25(3), 429-445.

Baker, M.P. \& Wurgler, J. (2002). Market Timing and Capital Structure. Journal of Finance, 57(1), 1-32.

BCBS. (2008). Principles for Sound Liquidity Management and Supervision. Basel, Switzerland: Bank for International Settlement.

Campion, A. (2000). Improving Internal Control: A Practical Guide for Microfinance Institutions. Micro Finance Network.

De Franco, A. (2005). Financial Management in Developing Countries. Pearson Publishers.

Diamond, D.W. \& Rajan, R.G. (2001). Liquidity Risk, Liquidity Creation, and Financial Fragility: A Theory of Banking. Journal of Political Economy, 109(2), 287-327.

Dusuki, A.W. (2005). Commodity Murabahah Programme (CMP): An Innovative Approach to Liquidity Management. Journal of Islamic Banking, 3(1), 1-23.

Freeman, R.E. (1984). Strategic Management: A stakeholder Approach. Boston: Pitman.

Greenbaum, S.I. \& Thakor, A.V. (2007). Contemporary Financial Intermediation (2nd ed.). America: Elsevier Publications.

Greuning, H.V. \& Bratanovic Sonja Brajoviv (2009). Risks associated with liquidity in the Islamic financial 
services Paris, Industry (IIFS). Third Islamic Financial Forum: The European Challenge, France.

Holsti, O.R. (1969). Content Analysis for Social Sciences and Humanities. Reading, Mass.: Addison-Wesley.

Hubbard, G.R. (2002). Money, the Financial System, and the Economy. New Jersey: The Addison Wesley Series in Economics, Pearson Education Inc.

Ismal, R. (2010a). Assessment of Liquidity Management in Islamic Banking Industry. International Journal of Islamic and Middle Eastern Finance and Management, 3(2), 147-167.

Ismal, R. (2010b). The Management of Liquidity Risk in Islamic Banks: The Case Study of Indonesia. Durham University Journal of Political Economy, 91(3), 401-419.

Kuncoro, and Suhardjono. (2002). Manajemen Perbankan: Teori dan Aplikasi. Banking Management: Theori and Application. Yogyakarta: BPFE.

Miles, S. (2011). Stakeholder definitions: Profusion and Confusion. IESE EIASM 1st Interdisciplinary Confer- ence on Stakeholder, Resources and Value Creation, Business School, University of Navarra, Barcelona.

Mugenda, O.M. \& Mugenda, O.G. (1999). Research Methods. Kenya: Acts Press.

Muhamad. (2009). Lembaga Keuangan Mikro Syariah. Islamic Microfinance Institutions. Yogyakarta: Graha Ilmu.

Obwocha, G. (2003). Financial Management Practices. Macmillan Publishers.

Ridwan, M. (2006). Baitul Maal wa Tamwil. Jakarta: Prenada Media Group.

Simplice, A.A. (2013). Post-Crisis Bank Liquidity Risk Management Disclosure. Qualitative Research in Financial Markets, 5(1), 6-84.

Taswan. (2006). Manajemen Perbankan. Banking Management. Yogyakarta: UPP STIM YPKP.

Umer, C. (2001). What is Islamic Economics? Jeddah: Islamic Development Bank \& IRTI.

Wood, Robert A. et al. (2004). Decimals and Liquidity: A Study of the Nyse. Journal of Financial Research. 